\title{
From La Vita é Bella, See How Film Against War and Inhumanity
}

\author{
Ruobing $\mathrm{He}^{1, \text { a }}$ \\ ${ }^{1}$ Faculty of Media and Communication, Bournemouth University, Bournemouth, BH12 5BB, UK
${ }^{a}$ ivyhe0616@gmail.com
}

\begin{abstract}
La Vita é Bella is a very representative work in the history of war films. Apart from its colour, storey and cinematography, the profound meaning contained in it also alerts many viewers. We will therefore use the film Beautiful Life to see whether works of art can affect the rejection of war by humanity and, if so, how it affects it.
\end{abstract}

Keywords: War, film, human nature, La Vita é Bella (Life is beautiful)

\section{INTRODUCTION}

Art works usually exhibit the author 's views and personality and bring into the work what they want to convey and say. Especially for sensitive subjects such as war or anti-humanity movements, many artists have created many anti-war films from various perspectives, projecting their views and positions, similar to Hayao Miyazaki 's work Castle in the Sky (1986), When the Wind Blows (1986) by Jimmy Murakami, The Reader (2008) by Stephen Daldry, etc. At the same time, this kind of work would have a significant impact on their audience's views.

In the history of human civilisation, wars lead by the confrontation of races, religions and nationalist selfidentification seems to have never ended. Even in the 21st century, which is changing rapidly, we can still see the shadow of past which has been left in today's society, such as terrorism. Christopher Catherwood talks about this situation in Why the Nations Rage: Killing in the Name of God (2002), he believes that neither religion nor nationalist self-identification can be ignored when such controversy occurs. It is not just religion and domestic pride, because the brutality did not emerge from just nationalistic disputes. The way they communicated instead leads to negative jingoism, worse racial affiliation and radical religions. Nationalism and ethnicity establish an ideology while religion describes the misery of a population, contributing to aggressive forms of conquering shame and disgust. Therefore, tolerance for other cultures in today's society has become especially important like what Gandhi, an Ahimsa believer who has mentioned in My Experiments of the Truth (2007) that love and tolerance are what we utilise to understand the integrity of every human being. For him, the greatest virtue is a forgiving soul. He assured that that the truth can only be found through tolerance and empathy for others, and to be nonviolent requires great courage. In such cases, La Vita é Bella, English name Life is Beautiful being a typical historical film from the viewpoint of a racial catastrophe that illustrates human nature, with exceptional imagination and satire, interprets an insufferable historical tragedy. It clearly reveals that during the Second World War under the Fascist dictatorship, the inexhaustible faith in love and hope which the Jew demonstrated in Nazi concentration camp.

\section{INFLUENCE OF LA VITA É BELLA}

There are many types of war movies on the market, Life is Beautiful is a very unique one among all of them. In addition to the plot that we are familiar with showing paternal love and brutal ruling, one of the reasons I chose to explain this movie is because of its director Roberto Benigni. In Grace Russo Bullaro's Beyond Life is Beautiful (2005), she points out that Benigni has only been known by his audience as an Oscar winner comedian, instead of the plenty of aspects of his career. Therefore, she aims to resolve this condition by emphasising on the "influences and forces" which she mentions that "will help us to understand the full, yet sometimes disputed or misunderstood artistry of Benigni; the one that goes beyond Life is Beautiful." She achieved this by pushing the audience into the claustrophobic chambers of the Holocaust polemics and led the audience of this film on a journey. The film has a profound impact on people, whether it is from a political or historical 
perspective. As Maurizio Viano said, "A common motif in the arguments of "the Holocaust fundamentalists" is that Life Is Beautiful pacifies its audience. The very existence of Beyond Life Is Beautiful, published six years after the film in the wake of myriads of articles and web reviews, is the proof that, far from pacifying, Benigni's film raised a storm, a storm which has intensely revived the memory of the Holocaust."

When Life is Beautiful was released in 1997, unlike the high reviews we see on IMDb right now, this movie was very controversial at the time. Just like what Maurizio Viano said in his article "Life Is Beautiful": Reception, Allegory, and Holocaust Laughter (1999) that examines the critical judgments on Life is Beautiful, conventionally presented within a low, medium and high hierarchy, indicates that the higher the position of the audience, the more pessimistic it would be. Maurizio mentioned, "Likewise, most of the film scholars that I have interviewed either shrugged their shoulders or expressed contempt." He found out that in Boston and New York City, the film was written in an optimistic way by the two key magazines, the Boston Globe (n.d.) and the New York Times (n.d.). And magazines which are aiming for more advanced readers such as the Boston Phoenix (n.d.) and the Village Voice (n.d.) utilise a more criticizing point of view. However, on the other hand, students were enthusiastic and many scholars from backgrounds other than film, including Jewish studies were extremely passionate. Maurizio believes that it then gives a limit to the middle and high-brow film authority, which impacts mainstream or no specialist viewers and those who seek film ratings from them. Criticism encouraged this film, including those who accused Benigni of trivialising the Holocaust. However, Psychology Today (2015) states that "The movie is a fable, not a reflection of reality. It portrays the way parents attempt to help their kids make sense of the senselessness life often has in store."

\section{DIFFERENT VOICES}

This movie shows us those who live peacefully, the dangers of war to people. Among them, as a father, Guido tried his best to create a beautiful fairy tale for his son in the miserable world of the concentration camp. Arthur Schopenhauer believes that a great value of being young is that people have such a keen and strong perception of life in the early stages of life. He has to go through a dream period and the process of recognizing the essential laws of things. This is a painful process. He once said in Either Lonely or Vulgar (2016) that the earlier young people are familiar with the world, the more mediocre nature is. The rough explanation of this sentence is too formulaic, but in the movie, although the media has many disputes about the male protagonist's protection of his son in the film, Benigni emerged this peculiarity. Which is supported in Stein's Wars I Have Seen (1945): In time of war you know much more what children feel than in time of peace, not that children feel more but you have to know more about what they feel. In time of peace what children feel concerns the lives of children as children but in time of war there is a lingering belief that there aren't children's lives and grown up lives, there are just lives and so quite naturally you have to know what children feel. Pamela L. Kroll explains this idea in Games of Disappearance and Return: War and the Child (2002) in Roberto Benigni's "Life Is Beautiful" that what Stein and Benigni realised is the key influence of the war on civilians are the loss of control over war, the 'home' and the environment to determine the 'time' of war. "A child's first sense of disorientation, helplessness and fear associated with the loss of mastery will gradually deepen and spread," he says. As the war progresses, "the effects radiate until every familiar element and routine of both the world without and the world within, has transformed virtually." Eventually, due to exhaustion of living in constant fear, "one's world - and even oneself - becomes utterly unrecognizable."

However, there are people who held the opposite opinion. Stuart Liebman questioned about Benigni's intent of making this film in If Only Life Were So Beautiful (1999), "What impelled Benigni to attempt a comedy about the Holocaust? Why now? Answers remain elusive and allow darker thoughts to surface. Did opportunism, or worse, cool calculation and a cunning assessment of audience susceptibilities, influence his choice of topic?" He especially emphasized on Benigni's family background as his father worked as a forced labourer for the Germans in the World War II, and "this graphical detail is undoubtedly relevant" as what he motioned. Stuart also believes that these gags which have been seen in the film don't just live by themselves. They have a political edge, which was cloned from the antiNazi satirical vocabulary of Chaplin's The Great Dictator (1940) and Lubitsch's To Be or Not to be (1942) more than half a century ago. Ilona Klein gave her explanation for this result in Life is Beautiful, or is It? Asked Jacob the Lair (2010) wondered whether humour within the Nazi ghettos was strictly prohibited and was used by Jews often as a way to relieve anger and horrors in daily life. Their amusement was just a tiny laugh: a hidden and secret smile. She reports The Christian Science Monitor (n.d.) writes "his fable ultimately obscures the human and historical events it sets out to illuminate. Its intentions may be sound, but its achievements fall far short of the ambitious mark it sets for itself." And herself claimed that "The film denies to its audience the traumatic historical impact of the Jewish genocide, while at the same time sugar-coating the deaths of the victims." Which is trying to transform evil recollection into an awarded game.

Therefore, although the film offers a snapshot of the horrors of one of the worst tragedies in history, it is far from the core theme of the film. Life is Beautiful is not a film just about Nazism, anti-Semitism, or even the 
Holocaust. It is a film of optimism and compassion that shines through even in times of utter inhumanity. It's about the undying love between mother, father, and son. It is about the promises given to their children in times of aggression and war, so that their children will enjoy a life much more glorious than their own, which I believe many parents can relate to when watching. Benigni's choice to create a Holocaust comedy has aroused widespread controversy and criticism. Many critics believe the Holocaust was 'ridiculed' by him. Benigni once retorted, "This is a huge tragedy, and I respect their reaction to it. I'm very sorry about this, but I don't understand it." (Logan, 1999) in addition, he said, "I didn't want to make a movie about the Holocaust - I wanted to make a beautiful film. But if this film has even in a tiny way helped get people to talk about this subject, to feel the absurdity and the incomprehensible folly... And if we can talk about it and also even smile about it, not sneeringly, but to naturally make fun of it, to smile at the Holocaust, we will be able to get over it, even though I can't say if it is wrong or right to get over it, but it has to be done somehow." (Stanley, 1998) However, contrary to his wishes, it still brought a huge impact on viewer's understanding of war and humanity.

\section{RELATIONSHIP BETWEEN FILM AND SOCIETY}

It has always been said in the past that news affects society, meaning that news has a supervisory effect on people. Could movies also transform culture and change the world as a work of art and literature? There are so many films in the history of film production that have had a significant influence on the real world. These films, based on the social status quo, or adapted from actual events, use films to communicate concepts to the public, allow people to see things that are overlooked and unknown, and then use the public's power to subtly alter conventional ideas, or directly facilitate the production of the bill. The film Philadelphia was the first Hollywood movie to focus on AIDS and homophobia as early as 1993 in the United States. This has made people begin to face AIDS. Ignoring the problem of AIDS has killed countless people before. (Millea, 2019) And you have to mention South Korea when it comes to films affecting the community events. The government attached great importance to the semi-basement residents in 2019, after several Oscars were won by the movie Parasite. The Seoul Metropolitan Government declared on the 18th that it would allocate funds to strengthen the housing conditions of 1,500 families living in the semi-basement, including upgrading the heating system. Up to 3.2 million won per household can be used to repair floors, instal air conditioners, dehumidifiers, ventilators, windows and fire alarm systems and other facilities. (Ock, 2020) Still in South Korea, on the 37th day of the release of the film, the Korean National Assembly passed the "Sexual Assault Prevention Amendment," also known as the
"Dogani Law" which carries the most extreme life imprisonment sentence and abolishes the trial period. (Rahn, 2011) Not only in South Korea, but also after the Chinese film Dying to Survive, the government has accelerated the introduction of necessary steps to ensure availability, such as reducing the price of cancer drugs. On 26 August 2019, Article 124 of the newly amended Drug Administration Law specifies that, if the circumstances are slight, imports of small amounts of drugs that have been legitimately put on the market abroad without permission can be excluded from liability and punishment. Later, the Chinese "Drug Administration Regulation" revision mechanism was encouraged, and more high-priced anti-cancer drugs were included in the reach of medical insurance, so that more average citizens could afford high-priced drugs. (Zhuang, 2018) Of course, social changes and legal changes are not solely the credit of a film. But it is the advent of films with similar themes that makes us become habitual and eventually awake, encouraging social transformation and systemic reform.

Similarly, society is influencing back to the expression of films. In MOTION PICTURES AS AID TO EDUCATION, ALFRED H. SAUNDERS claimed that almost all significant events in world history have been captured on film in thousands of languages since the Boer War and transmitted to all nations. It is said that it is always hard to choose a fitting theme during the production period, and any products that producers want to sell to the public are shown by exhibitors. It would not please the French audience, although many of the topics are in French. Around the same time, some of the audience thinks the pictures content was too board as they are introduced into countries with more special aesthetics such as the United States and the United Kingdom. This has increasingly influenced the tradition of establishing a joint stock company to complete the competition under the supervision of a mature stage manager, thus a new career called screen writer arises. (Alfred Henry Saunders, 1913) Nevertheless, in Annemarie Kersten's paper, she claimed that, while transnational disparities can be clarified in part by different principles reflecting national guidelines of cultural appraisal, various other social characteristics deriving from countries' social, economic and cultural experience are also likely to sustain different results. For instance, America 's emphasis on production reality is consistent with American film industry 's long-term supremacy and economic significance. And France's continued emphasis upon artistic ideals can be attributed to its historic central role in Europe's cultural and literary life, as well as in the growth of self-awareness as a philosophy of the film industry. The Netherlands' uncertainty seems sufficient to open up to the multiple force characteristic of small countries and the absence of a clear social hierarchy. The balanced discourse of Britain may be a consequence of the deterioration of the strong class structure and the country 's influential mass cultural industry. 
Annemarie suggests there could be many influences influencing the social significance of culture in the sense of a region. (Kersten, 2014) For example, the third most popular film in Mexico to date is a political satire, full of hypocrisy and nepotism, which made Mexican policies famous, with Mexican film director Luis Estrada's The Perfect Dictatorship. It also portrays the present President satirically as the first film in Mexico 's history. For Mexico's freedom of expression, it was a huge success. The film of Luis Estrada, Carmen Irabien Chedrauve claims, it is a pretext for writing about the corrupt political climate of Mexico and its negative effect on the reputation of Mexico. This film thus offers a new way for Pena Nieto to be criticised during his tenure. From the aforementioned examples, we can see that the development of movies is a microcosm of the evolution of our lives with the development of the entertainment industry, from silent to sound, eventually developing to three-dimensional film and television effects. (Chedraui, 2016) In people's spare time, movies become part of the lives of individuals, but movies also come from life, and movies also represent life. It increases the capacity of people to view the environment, has a new perception of the world and the nature of cinema, and also changes the behaviours of people. Films have a tremendous effect on human life.

Some people, such as the court, however, assume that film exhibits are only a business that cannot be neglected. As other plays, it should be pure and plain for benefit, and should not be considered as part of the media. They merely represent the release and perception of events, thoughts and feelings. (Mutual v.Ohio, 1915) This muchcited passage, Jennifer Petersen argues, is full of parallels both to the political interest and the interpretation of the film nature by the judges. (Petersen, 2014) In La Vita e Bella, one of the biggest controversies is whether director Benigni really considered the massacre a joke. (Logan, 1999) Let us not to argue with if the director was paying his respect, sometimes I wonder about whether if the perspective is able to affect people watching the film. Or man, such as politicians, will use films as the blind spot in so-called "pure works of art" to guide people's opinion towards government or politics? Study by Michelle C. Pautz from the two films Argo and Zero Dark Thirty showed that many people in research shifted their perspective on the government after the screening of those films. Most citizens have higher levels of government confidence and therefore have a more optimistic outlook on government efficiency. She concludes that the time and events depicted in the film and the time the film was made and viewed can be significant. The old the case, the less the audience remembers it, or knowing the event goes beyond the boundaries of the school can be rendered a feasible claim. This can contribute to films becoming more capable of manipulating perception. The period also obscures the memory of people's details and how they have influenced our government views. Secondly, a further theory of this inquiry concerns film as a key element of the medium of narration. More distinctive films and institutional elements will affect the viewer even more. In other words, film will influence their viewers if it is easier to recognise "good guys" and "bad guys." Considering the constraints of the media such as narrative, time and economic, films strive to simplify the plot and make it easier for the storey and characters to be portrayed in a more unidimensional manner. (Pautz, 2015) Back to Life is Beautiful, Brian Logan pointed out in his press release after meeting Benigni that there had been a few errors in the films used in Benigni, but these mistakes had been made in order to make his films far away from the history. Benigni said only the survivors' documentary and the majesty of reality would teach us the play. We could mimic otherwise, which is irrespective. He is respectful of this disaster, too far removed. It doesn't use tomato soup thus and doesn't contain false blood. In addition, the director said he needed to know if this movie might harm or upset anyone. Then the script was submitted to Milan's Jewish group, who told him they liked the design. (Logan, 1999) We know that films are one of the influences leading to civil political socialisation. We can tell from these examples, when viewers analyse the performance of the government in films, it is simple to infer that movies have a negative effect on government as expressed by public opinion, despite the reality could be more complicated. (Pautz, 2015) And this is not just towards the politics, but also the mind of the director. We can see, therefore, that art works are closely linked to society, culture, and even to us, and that they all significant influencing each other subtly. The so-called art originates from life, and life can also come from art.

\section{CONCLUSION}

There is a popular phrase so-called art is originating from life, and life can also come from art. From this film, La Vita é Bella offered its audience a deep visual feast from different perspectives. In particular, how it humorously depicts the visual strategies and narrative techniques of that very horrific conflict, which also reminds us of past scars. War still persists in today's world. Zygmunt Bauman's Modernity and Holocaust (2012) has an in-depth analysis of the Nazi holocaust of the Jews. He believes that this is the inevitable consequence of the over-expanded rationality of modernity: morally, neutral science dominates, the manipulation of human nature 's fear of aliens makes the public indifferent; technologically advanced technologies have made mass killings possible; organizationally, the bureaucracy that best meets the efficiency requirements of instrumental rationality. What is even more frightening is that this rationality not only makes the abuser powerful but also restricts the victim. Everyone actively participates in self-management with a self-preservation mentality, while remaining indifferent to the miserable situation of others with the same fate. The same logic is 
reflected in the massacre in Indonesia and the massacre in Rwanda. Even two years after the film was released, there was a similar incident in the Yugoslavia in Eastern Europe: racial opposition between the Albanian and the Serbian, which now has evolved into war. When thinking of the oppression of the Jewish in the World War Two, I wonder whether people have really learnt anything from history? To this day, disputes about race continue to exist. For example, the "Black Lives Matter" operation that ignited the world a few months ago. It is true that a film may not be able to influence the decisions of politicians, but it will have at least a slight impact on people, whether it is a reverence for life, a rejection of war, or a perception of human nature.

\section{REFERENCES}

[1] Bauman, Z. (2012). Modernity and the holocaust. Cambridge; Maldon: Polity, Cop.

[2] Catherwood, C. (2002). Why the nations rage: killing in the name of God. Lanham, Md.: Rowman \& Littlefield.

[3] Gandhi, M. and Mahadev Desai (2007). An autobiography, or, The story of my experiments with truth. London: Penguin.

[4] Grace Russo Bullaro (2005). Beyond "Life is Beautiful": comedy and tragedy in the cinema of Roberto Benigni. Leicester: Troubador.

[5] Klein, I. (2010). “Life Is Beautiful, Or Is It?” Asked Jakob the Liar. Rocky Mountain Review, [online] 64(1), pp.17-31. Available at: https://www.jstor.org/stable/25677053.

[6] Kroll, P.L. (2002). Games of Disappearance and Return: War and the Child in Roberto Benigni's "Life Is Beautiful." Literature/Film Quarterly, [online] 30(1), pp.29-45. Available at: https://www.jstor.org/stable/43797066.

[7] Lee, J. (2018). Film and Television. [online] JSTOR. Available at: https://www.jstor.org/stable/j.ctv56fgmk.5.

[8] Liebman, S. (1999). If Only Life Were So Beautiful. Cinéaste, [online] 24(2/3), pp.20-22. Available at: https://www.jstor.org/stable/41689137.

[9] Schopenhauer, A. (2016). Either Lonely or Vulgar (Hardcover) (Chinese Edition). 1st ed. China: Jiangsu literature and Art Publishing House.

[10] Science, C. (n.d.). The Christian Science Monitor. Editorial: Christian Science Monitor.

[11] Stein, G. (1945). Wars I have seen. New York: Random House.
[12] Viano, M. (1999). "Life Is Beautiful": Reception, Allegory, and Holocaust Laughter. Film Quarterly, [online] 53(1), pp.26-34. Available at: https://www.jstor.org/stable/3697210.

[13] VIANO, M. (2006). Beyond Life Is Beautiful: Comedy and Tragedy in the Cinema of Roberto Benigni: Beyond Life Is Beautiful: Comedy and Tragedy in the Cinema of Roberto Benigni. Film Quarterly, [online] 60(1), pp.61-62. Available at: https://www.jstor.org/stable/10.1525/fq.2006.60.1. 61.

[14] Logan, B. (1999). Does this man really think the Holocaust was a big joke? [online] the Guardian. Available at: https://www.theguardian.com/culture/1999/jan/29/a wardsandprizes.

[15] Stanley, A. (1998). The Funniest Italian You've Probably Never Heard Of. The New York Times. [online] 11 Oct. Available at: https://www.nytimes.com/1998/10/11/magazine/the -funniest-italian-you-ve-probably-never-heardof.html.

[16] Ock, H. (2020). Seoul to improve living conditions in semi-basement apartments depicted in 'Parasite.' [online] www.koreaherald.com. Available at: http://www.koreaherald.com/view.php?ud=202002 18000706

[17] Millea, H. (2019). Looking Back at "Philadelphia," 25 Years Later. [online] Smithsonian Magazine. Available https://www.smithsonianmag.com/artsculture/looking-back-philadelphia-25-years-later180971011/ [Accessed 9 Nov. 2020].

[18] Rahn, K. (2011). National Assembly passes 'Dogani Law'. [online] koreatimes. Available at: http://www.koreatimes.co.kr/www/news/nation/20 11/10/113_97529.html.

[19] Zhuang, P. (2018). 'Dying to Survive' gets real: China cuts price of life-saving cancer drugs. [online] South China Morning Post. Available at: https://www.scmp.com/news/china/society/article/2 168136/dying-survive-gets-real-china-cuts-pricelife-saving-cancer-drugs [Accessed 9 Nov. 2020].

[20] Pautz, M. (2015). Films can have a major influence on how people view government. [online] USAPP. Available at: https://blogs.lse.ac.uk/usappblog/2015/03/12/filmscan-have-a-major-influence-on-how-people-viewgovernment/.

[21] Petersen, J. (2014). Can Moving Pictures Speak? Film, Speech, and Social Science in Early 
Twentieth-Century Law. Cinema Journal, [online] 53(3), pp.76-99. Available at: https://www.jstor.org/stable/43653621 [Accessed 9 Nov. 2020].

[22] Mutual v.Ohio (1915). Mutual Film Corp. v. Industrial Comm'n of Ohio, 236 U.S. 230 (1915). [online] Justia Law. Available at: https://supreme.justia.com/cases/federal/us/236/230 I.

[23] Alfred Henry Saunders (1913). Motion pictures as an aid to education. WASHINGTON: GOVERXMENT.PKINTINGOFFICE.

[24] Kersten, A. (2014). National Cultural Repertoires of Evaluation in a Global Age: Film Discourse in France, the Netherlands, the United Kingdom, and the United States. European Sociological Review, [online] 30(6), pp.717-727. Available at: https://www.jstor.org/stable/24479808 [Accessed 9 Nov. 2020].

[25] Chedraui, C.I. (2016). The Perfect Dictatorship: Political Satire in Contemporary Mexican Cinema. Cinéaste, [online] 41(3), pp.44-45. Available at: https://www.jstor.org/stable/26356426 [Accessed 9 Nov. 2020]. 